Received: 10.09.2012.

Reviewed paper

UDK: 78-056.45:372.878

\title{
RECOGNITION AND SUPPORT PROGRAM FOR CHILDREN TALENTED FOR MUSIC AT JUNIOR AGE OF SCHOOL CHILDREN
}

Biljana Jeremić, MSc, assistant of Music Education, Faculty of Pedagogy - Sombor (Serbia)

e-mail: mrbiljana@gmail.com

\section{SUMMARY}

Recognition of gifted pupils at the junior school age is a very significant factor for development of biologic potentials of the gifted individuals. Recognition of gifted pupils according to the legal norms of the Republic of Serbia a priori implies the right of the gifted pupils on an individual education plan (IEP in the following text) and on the pedagogical and expert support of the expert teams. We will be dealing with musically gifted pupils who do not attend Music school in this work. The task of the expert teams is to establish the IEP for musically gifted pupils and to direct them into development of the gift using the holistic approach. This implies the stimuli for motivation and interest for work of the pupils. Furthermore, it also implies the development of moral behaviour, emotional intelligence and social maturity. The IEP for a musically talented pupil contains five phases presented in this paper as example part of pedagogical practice.

Keywords: music talent, expert team, individual education plan, pupil 


\section{INTRODUCTION}

"Use those talents you have. You will make it. You will give joy to the world. Take this tip from nature: The woods would be a very silent place if no birds sang except those who sang best".

Meltzer Bernard

It is the fact that the gifted individuals are the wealth of a society in every sphere of life. Democratic nations invest enormous efforts in recognizing the gifted individuals as early as possible to be able to give the system support that would be later reflected in individuals' creativity in different areas of social activities. The gifted bring along huge progress to their societies and huge spiritual and material benefit. In developed countries much is invested in identification of talents and there are talent scouts, experts who succeed in recognizing above-mediocrity, in some of social useful spheres at very early age of a child.

The phenomenon of talent, anticipated through valuated tests, estimates and longitudinal researches, have been introduced and worked on not earlier but in the beginning of the twentieth century. Monitoring talents through the aspect of a historical distance we can conclude that many scientific and artistic deeds were praised only many years after their creators' death. Unfortunately, many great minds were considered weird while alive. In the whirlpool of illiteracy and ignorance works of today highly estimated scientists are found in utterly unusual places. Neither the music geniuses skipped this misfortune. The extraordinary Mozart whose death his contemporaries did not experience as a spiritual loss of the complete humanity, but as something usual and part of mediocrity of someone's life. Many years later music experts concluded that his genius exceeds all temporal distances and that he was unique in all domains of music creativity. The essential, not just a rhetorical question would be: where would his talent and genius end if he had optimal life circumstances?

Therefore the necessity of recognizing the gifted individuals on time and at early age, especially when we consider the musical talent, is the topic of this work. Music enriches human identity as unique of the kind in the widest sense. Furthermore it marks and distinguishes each national, religious and racial particularity. It wears the epithet of the most human substrate which annuls the boundaries of not knowing languages. The beauty of melodies is understood by each man in his own way. Music annihilates all boundaries and merges human kind into a unique biopsychosocial shape.

It is often the case that although gifted, children do not succeed to realize themselves, neither in professional nor personal life. The reasons for the failure could possibly be the lack of pedagogic support at school or misunderstanding of their social surrounding for their diversity according to the average population. Parents of the gifted children do not succeed to follow their talent. Individualized work with gifted children is ongoing in Serbian elementary schools during the last few years. Holistic approach is used towards them to avoid detaching their talent from the context of their personality. This is monitored by the experts in the form of the IEP. The teacher usually coordinates the 
team. It is necessary to emphasize the role of music teacher and school psychologist. The members of the team would, in collaboration with pupil's family, identify the gift in a child with intention to obtain the optimal surrounding for development of his or her biological potentials. Therefore, motivation, working habit formation, moral and pro-social behaviour would improve analogically with the gift of the children.

\section{THE RECOGNITION OF MUSIC TALENT}

Humanistic approach accent that every child has a gift, talent, exceptional capability. A gift, talent or exceptional capability is not just always obvious and explicit. Every child should be provided the opportunity to express themselves in different experiences to develop different skills, attitudes and knowledges. Therefore it is necessary to detect the talent and nourish it. Motivation is the basic driver, it tis the inner impuls in coherence with creativity. Creativity is most often analyzed in the context of talent as people belongings, behaviour or products (Maksić, 2006).

There are numerous definitions of talent. They are aiming the different aspects of the notion. They define talent from different psychological angles and they refer to outstanding capabilities in certain fields. Gardner $(1983,1997)$ identified seven different inteligences. One of them is music ability which enables the individuals sensitive to it to differenciate, manipulate and create new auditive music messages. Both psychologists and musicians deal with the question of capabilities. They often use "numerous terms as gift, talent, music capabilities, potential, capacity, having a musical talent which are not precisely defined and used in different contexts sometimes have vague meaning" (Bogunović, 2008:73). Music capabilities are defined as „capability of hearing, perception, and vocal or instrumental reproduction of melodic and rhythmic content on the basis of musical hearing" (Radičeva, 1997:91). According to Teplov (1967) talent consists of musicality and musical talent. Musicality enables someone deal with music and being musically gifted besides musical, special features, consists of numerous other capabilities of rather general features. Mirković (1998) maintains that music capability presents the gathered inheritance and the things that are learned, resultants, capacities, i.e. innate dispositions gathered with maturing; informal early experiences with music acquired under the influence of environment and formal music learning. According to Koren (1989) there are pupils in school population who have particularly developed capability of divergent thinking, originality and flexibility. They express themselves through new spiritual and material products. In those cases we talk about talent implying creative capabilities.

Early childhood music educators are committed to supporting children's music learning, or they would not choose to teach young children on a regular basis. Yet, much of what Gordon has discovered through decades of research has not been put into practice in early childhood music classrooms (Taggart, C. C., 2011).

Edwin Gordon (1980) believes that learning music at the lowest level of discrimination involves listening to recordings of music, singing with neutral vowel and performing music by mimicking the teacher's voice through singing and movement. The Gordon 
Music Learning Theory (Gordon, E., 2001) is called Audition and it is a music learning theory that focuses on the process of mental hearing and understanding of music when the sound is not actually physically present. The essence of children's musicality according to Gordon $(1965,1979)$ lies in the awareness of the identicalness, i.e. diversity of what children hear. Therefore, musicality tests by this author examine the elementary achievement as an expression of existing musical potential of the child. The obtained information is valuable for music educators who are looking for effective ways to teach children music (Gordon, E., 1984). The Gordon Music Learning Theory Audition introduces sound before the symbol which is also the Dalcroze (Jaques - Dalcroze, 1965) Music Learning Theory, which is reflected in the perception of rhythm through movement and represents a major contribution to the music education of children. His theory is based on the fusion of sensory and intellectual experience through which the "skills and understandings from the lowest to the most accomplished musicians, have been built on the active participation in musical experience" (Landis and Carder, 1972:9). The conception of rhythm according to Dalcroze is like the relationship of man, nature and art (Jaramillo María Cecilia Jonquera, 2004) and it is very important for the development of musicality from the earliest age.

According to Huzjak (2006) early identification of gifted children is detected if they start playing an instrument at early age and do it with great desire. Their auditive memory is above - mediocre. They show creativity with the capability to improvise because they easily comprehend music structures. They easily realize rules and logical patterns, since they remember with more quality the diatonic scale from dissonant music structuralized on chromatic scale. „The talented move freely among the four ways of approaching to music work changing the center of attention among the instruments, playing technique, score and tone and music structure. They have increased sensitivity for differentiating timbre" (Huzjak, 2006: 291).

Submitted opinions and attitudes about musicality, musical talent and about music capabilities are different, but they lead towards detecting the musical gift and influencing its development as early as possible. All theories emphasize capabilities as the initial state and aim to the pupils distinction. Psychology teaches that human capabilities are assigned in population „forming a bell - shape curve most of people have certain ability developed on an average level, while the number of people with higher or lower level of development of the ability is symmetrically reduced" (Koren, 1989:7). Specific music capabilities i.e. musical talent at the junior school age is the topic of this work. We are going to try to define musical talent exposed on regular Music classes.

Author of this work agrees with many who think that talent for music implies being gifted with musical capabilities, being musically gifted. Expressing musical talent at the junior school age depends on numerous factors. The pupils who grow in musically friendly surrounding attend Music school where their talent for certain areas of music is directed by music teachers. The question is what about the pupils who possess the musical talent, but for a certain reason were not given the opportunity to attend Music school. As a metter of fact, every child is gifted, he possesses certain level of musical capabilities as musical talent. Talent is therefore outstanding capability for reacting, experiencing and expressing certain innate or learned potential exposed in musical capabilities. By noticing affective, cognitive 
and reproductive capabilities of pupils, and recognizing the sensibility for reacting, experiencing and expressing the sense for rythm, melody and certain components of a music work we set conditions for detecting this kind of gift, the musical talent, so the talent can be directed and developed (Jeremić, 2011a). The teacher detects musical talent through his teaching practice of playing music and monitoring all pupils singing and playing.

The role of school and the teacher in realizing the content of the plan for subject Music is very significant. It illustrates the way every individual and his musical talent develops under the influence of education in the process of learning. According to the regulations for IEP (Službeni glasnik RS, number 76/10) and to a pedagogic profile of a child, i.e. pupil, areas are established in which there is a need for an extra support in education. It is also planned to eliminate physical and communicational obstacles (individualized way) in educational work.

Pursuit for a creative profile is based on a congruent model of creativity which explains that effective creative behaviour comes from multiple interaction: intellectual processes, knowledge, intellectual style, personality, motivation and surrounding conditions (Radovanović, 1989).

\title{
INFLUENTIAL WORK OF TEACHERS AND EXPERT TEAMS ON DEVELOPMENT OF THE GIFT FOR MUSIC
}

\author{
"Teacher is a person who makes tough things easy"
}

Ralph Waldo Emerson

On the way of growing up every child goes through different influences of his surrounding that form his personal dispositions. Influences come from his family which is constantly present and kindergarten before he begins attending school. Matijević and Bognar (2005) maintain that the basic factors in educational processes are the initiators, creators and the realizators - teachers, pupils and parents. "Interrelations among pupils and their relation towards their teacher determine the atmosphere of educational work. Teacher is responsible for good or bad learning situation" (Jurić, 1988:79). Teacher can influence the development of the musical talent by activating the capabilities which children bring along from their families and enabling them to develop according to their individual maximum. Kindergarten teacher, school teacher and pedagogue or psychologist monitor the development and improvement of the child, i.e. pupil during the learning and the development in learning the skills of learning, his social development, the development in communication and gaining self-confidence in independence (Sl-glasnik 76/10). The role of the teacher is quite significant in the work with the children who do not origine from the music stimulative families. "All children do not live in the same surroundings nor in the same circumstances" (Jovanović, 1972:16).

Elementary school is a place where gifted children cannot satisfy their love and interest in music through regular curriculum. The educational plan anticipates additional work with those children. They are to be involved in different groups with vocal drills or 
even better they should be offered to sing as solo singers in choir or to participate as players in orchestras. The teacher must be musically talented he needs to be creative and well educated for teaching music as he is responsible for the fulfillment of the aims and tasks planned for this subject. The teacher must be ready according to his individual maximum and personal interests to be able to enable the gifted pupil use, practice and improve his musical talent. The essential thing is to motivate the gifted pupil to fulfill the aims and the expert team with their leader, the teacher, should never neglect that. Motivation is, therefore, important as the will to tend to realize the task in spite of all obstacles and failures. The motivated children tend to make progress and reach the highest quality. They are ready to use the offered opportunity and reconcile it with the aims of the group or organization (Suzić, 2001). These complicated processes are realized through regular curriculum with all the pupils irrespectively to their individual music capabilities of musical talent and along the way the teacher notices musically talented pupils. That is why teacher's aims are complex and high, because premature or incompetent estimates of the pupils who have difficulties to comprehend music content would probably make the pupil be characterized as lacking the ear for music or musically untalented. Therefore, the teacher is a mentor, expert, leader, consultant, friend, parent and model who directs development of interest towards art. In that case, according to Gajić (1999) the very person is not the product, but the creator of his own development. Creating the music expression through basic means of the music expressions: rhythm, melody, harmony, dynamics, tempo, articulation and the variety of tones, the teacher will direct every musically talented pupil towards his own specific development. A child's nature deals with his developing skills, temper and personality. „Education, however, deals with the skills of parents and other people who take care about the child and their temper and their personal characteristics" (Glascoe, 1996, 106). This process, by all means, demands teacher's readiness, either educational and musical, and it is not quite popular nor easily applicable. This way of work obtains the satisfaction of motivation and interest of musically talented pupils. The sole interest urges learning and is what we call „the positive attitude towards the subject and the specific kind of curriculum" (Vučić, 1991, 75).

In Serbia recognizing a talent and creation of an individual educational plan (IEP) is regulated by the legislation from the end of 2010. The law enables pedagogic support to the musically talented pupil including child's parents or guardians in planning and work. In the end of October 2010 the Government of the Republic of Serbia adopted the Regulations for IEP with the precise instructions which enables the gifted pupils to be worked with according to the individual educational plan which is to be made for their specific capabilities by the expert team. The realization of the IEP anticipates planned and organizational solutions which allow the pupil advance faster in achieving the aims of the program. The expert team bares in mind that the high scores in mental spheres of the pupil do not imply socioemotional maturity. Therefore, they exhibit the balance between pupil's potentials and insufficient psychic maturity to deal with his far over average results. The teacher and the expert assistant (a pedagogue or school psychologist) collect data from different resources about the child, pupil, (from parents or guardians, experts who do not work in his school but know the child well, from his classmates and other schoolchildren of his age who know him, and from the very child, pupil, in the way it is possible). Different kinds of techniques 
are used in this process of collecting data. Expert assistants use systematic monitoring of the activities of the child in different situations, by testing and interviewing and fulfilling the questionnaires by pupils and other people who know the child, i.e. pupil (Sl.Glasnik 76/10).

IEP can be written for a part of the pre-school plan or complete pre-school plan, while at school for a part or a field within a subject, a group of subjects or for all contents, subjects for the year the pupil attends. It can also be made for extracurricular activities at school.

School makes adjusted and enriched IEP for every gifted pupil according to part 3. of paragraph 5. of the Regulations with precise instructions about IEP writing. This means that IEP is made for children not earlier but when they come to elementary school.

Official records about the educational realization of IEP is kept in the means and in the way the Regulations instruct. The records about IEP is a component part of pedagogic records regularly kept at school.

\section{DESCRIPTION OF IEP}

Every pupil with outstanding capabilities who acquired the right for elementary education has the right on a specialized and enriched educational method in the form of IEP. This includes musically talented pupils at the junior age at school. The IEP for a musically talented pupil contains five phases and is performed in the following procedure.

\section{The first phase - Recognition and monitoring}

The most important task of a teacher is to detect child's musical capabilities talent and to direct their further development. In the process of detecting musical talent, the teacher constantly monitors and evaluates the capabilities of the pupil and collects the data that reveal musical gift. He must establish and identify the cluster of music capabilities that make the musical gift. He uses the method of monitoring and estimation in the educational process during the classes of Music to establish the level of music capabilities of every pupil. His focus is on the tokens of expressed music capabilities in his group work with children expressed as working with joy, confidence and precision performing counting rhymes, singing songs with sensitivity and doing all that with precision, with correct intonation and with affective expressions performing the learned song. A musically talented pupil expresses open mind for new educational contents and motivational and esthetic features of experiencing the music contents. The teacher monitors development and improvement of his pupils during the process of learning, therefore in the classes of the Music education as well. If according to the results which a pupil achieves, there is to be concluded that he acquired much more knowledge from his classmates, then the teacher suggests the school pedagogue and psychologist, to consider creating IEP for the pupil with outstanding musical capabilities. Pupil's parents of guardians must agree with the realization of IEP. 


\section{The second phase - Expert team forming}

To enable the child to realize his talent and to obtain as optimal development of the child's talent as possible it is needed to form the expert-inclusive team. The team for the musically talented child includes his teacher, music teacher, psychologist and his parents. Initiating the process of creating of a IEP for the additional support in education has the same procedure for every child, either if his abilities are estimated to be having difficulties in learning or that he is with extraordinary capabilities. The expert team for inclusive education initiates the process of creating IEP if a child, i.e. pupil, cannot achieve the result level of education made for mediocre children. When it is realized that he cannot achieve the general nor specific standards of achievements caused by invalidity and any other reason for having difficulties in his development, or, however, if the child is with outstanding capabilities, so he can and does achieve results which are above the level of general and specific standards. The suggestion for creating IEP should consist of precise explanation of specific features and elaborated reasons for creating IEP, together with the records from the previously organized individualized ways of work with the child, i.e. pupil (the forms are introduced by Regulations for IEP) which are the component part of educational documentation and is archived. The child's parents, or guardians confirms, by their signature, that they are informed about the suggestion to use the right for IEP, about the reasons to initiate the creation of IEP, and that they agree with the suggestion for creating IEP for their child (Regulations for IEP). When a musically talented pupil is in question, then the leader of his expert team is usually his music teacher who suggests the plan. He is in the team with the teacher, psychologist, parents and the director. They have meetings every two or three weeks and follow pupil's improvement and give further suggestions to enrich the program respectively to the improvement.

\section{The third phase - Collecting data for IEP}

Teacher writes: personal data and he gives short insight about the development and educational situation and the status of musically talented pupil; the aim of the educational work, i.e. the change which should be achieved in the field with additional support; description of the support through all the steps and activities, with their specific order on Music classes, and description and agenda of extra - curriculum work when necessary; special standards of improvement and adjusted standards for Music classes at school, and the achievements of the activities which through thorough process lead to the aim by the help of additional support; timetable, duration and frequency for every mean of support in the term of the planned activities on Music classes.

\section{The fourth phase - Implication of IEP}

Teacher performs the individualized education with the musically talented pupils with help of the expert team and especially with the music pedagogue. Music teacher 
gives instructions about the contents of IEP in the individualized work with the musically talented pupil. Music teacher is at the same time included in the supplementary work with the musically talented pupil applying the activities assigned for that particular pupil in IEP. One of the ways of working with musically gifted children is their grouping on the criterion of their field of talent. Musically talented pupils are selected into choirs in elementary schools. There their musical talent can be expressed, realized, motivated and praised. Choir is a heterogenic group of musically gifted children in homogeneous structure of the performing a music work and one of the best ways to realize the capabilities of musically talented pupils. As support to teachers in talent recognition and application of IEP (Jeremić et. al., 2011) the teacher uses a test to check musical capabilities and SSCO (Systematic Syntax Classification of Objects), IT apparatus to find out how should the teacher notice and recognize the child who comes from musically stimulative surrounding to develop talent for singing in the choir. The chart exposes the rules which determine the connections among the answers of the interviewed talented child and the opinion of the music expert.

\section{The fifth phase - Evaluation}

Evaluation of IEP is done to estimate the realization of aims, set by IEP. On the basis of the evaluation, the support team suggests changes and additional adjustments of IEP according to child's, i.e. pupil's needs. The changes of IEP are made in accordance with the child's development and improvement; if he achieves the planned results before the set term or fails in achieving them; or if certain changes occur in the child's behaviour or his surrounding. Evaluation is done at the very beginning of IEP application as initial test and is repeated every three months. Therefore the development of the talent is monitored and the further work is directed. Jeremić (2011) has made the evaluation scale of vocal capabilities at junior school age by using musical capabilities test. The scale consists of music examples (melodic or rhythmic) according to which it is possible to evaluate vocal capabilities of a child, his singing talent which is at junior school age easily noticed through singing songs (educational contents are acquired through experiencing them while singing). According to the items on the first scale teacher will know if a pupil is talented, what will be confirmed by the answers to the questions and work on the tasks. The elements for vocal capabilities check (melodic and rhythmic) aiming the evaluation of vocal talent can be used for evaluation of musical capabilities of pupils at the junior school age. IEP is in use from the end of 2010 on. 


\section{A SPECIFIC EXAMPLE OF AN IEP FOR A MUSICALLY TALENTED PUPIL}

\section{The first phase}

The teacher identifies a child who is outstanding in his music capabilities in comparison to his classmates. The recognition of a pupil denotes that he memorizes and reproduces songs on a chime bars with expressing outstanding vocal capabilities in comparison to his classmates. According to the scale parameters (Jeremić, 2011) the pupil expresses his outstanding vocal capabilities. A pupil with these characteristics has the right on an IEP.

\section{The second phase}

Expert team is formed, and in this case it consists of teacher, music teacher, psychologist and the school director. It monitors the realization of IEP.

\section{The third phase}

The teacher collects all documentation needed for IEP application.

\section{The fourth phase}

During the estimation of music capabilities the music teacher notices pupil's melodic sensibility and vocal capabilities. He notices that the pupil sings with ease, but his voice range is rather limited and he is reluctant to sing at the moment of performing. Since it is a pupil with outstanding music capabilities, with distinguished vocal capability, music teacher creates the plan of activities which is to develop and improve child's musical talent. He uses selected music examples in work on elements of vocal techniques which enlarge the range of voice and he works on expressive elements of songs to introduce the esthetic side of the songs to the pupil. Therefore, music teacher introduces the basic elements of the song to be easily understood by every pupil. Along with the individual additional work with the pupil, music teacher invites the talented pupil to the extra-curricular activity - the choir. At the same time he instructs the teacher how to work with this pupil in the class. The activities which the teacher performs aim to the development of melodic capabilities and music memory. The pupil is to play the selected songs, which are the part of regular educational program, after hearing his teacher reproducing it. The songs are shorter melodic phrases at first, to become a long music period after the first trimester. The parents and the psychologist give the child additional support which concentrates on gaining self-confidence and socioemotional stability. Distinctiveness is often experienced as an obstacle to realize social relationships and that could be the obstacle for a pupil to realize his music talent to its pitch. That is why multidisciplinary 
holistic team approaches the child not only to improve the music talent but to extract the capability of the pupil to comprehend it as advantage and mediocrity in the context of his existence. The pupil is informed that by developing the talent and by practicing the additional work he increases his capacities to affirm himself, afterwards, as an expert at his middle-age. However, he should fulfill all his regular pupil duties as every other pupil of his age. This fact is important because lacking the sufficient psychological-pedagogic support, a talented person is incapable to deal with his above the average potentials. The school director presents the logistic support of the expert team because he provides additional teaching appliances and instruments, or pays for the trips to enable the pupil participate on competitions. We deal with a pupil in grade one and when he achieves the outcomes of this subject further application of IEP directs the pupil to the outcomes of Music for the grade two, to be able to get to the outcomes of this subject for grade three in the third trimester. Acceleration of the contents improve the music talent. The set aims of IEP for musically talented pupil are altogether directions for the talent. This IEP draft shows the importance of multidisciplinary team work, and the fact that music teacher should work together with the teacher, psychologist, parents and the director.

\section{The fifth phase}

The initial examination is done at the very beginning according to the evaluation scale of vocal capabilities on the bases of the test for pupil's musical capabilities (Jeremić, 2011). On the bases of subtests and items, initial state is observed and is measured by the same scale after the trimester. The pupil shows outstanding music capabilities, but not according to all subtests. That is why certain IEP in application is directed to development of certain components of music capabilities. After every measurement and evaluation the directing and planning of further activities are gradual in setting more and more complicating tasks for developing musical and vocal capabilities.

\section{CONCLUSION}

Future researches will confirm how efficient the legal support will be in recognizing and identification of children gifted for music. It is anticipated that despite the crisis of transition, these results are going to be better in the comparison to the results from the earlier period. Talent cannot wait for better times. Unless the support programs are introduced, talents would be wasted instead of being advanced.

The complete elaboration of the topic obviously illustrates that the processes of recognition and development (evaluation and acceleration) of musically talented children is very complex. They demand optimal surrounding conditions in which they will be performed (family and school - teacher), motivated and expressed. It must be mentioned, once again, that possessing the gift does not imply that the gift owner is going to be successful neither on personal nor professional area of his life. Individual educational plan should treat a pupil as a complete person and adjust it to him to enable the de- 
velopment of his bio-psycho-social potentials. Insufficient social competence or similar factors would possibly cause the complex of inferiority although the pupil in one or more socially useful fields is high above average pupils of his age. Proper development of pupils should be considered from the aspect of motivation, morality, socioemotional and many other aspects which should be the concern of the pupil's teacher, Music teacher, pedagogue, psychologist, family and social environment in which the pupil lives and grows up. Work of the expert teams is mostly multidisciplinary. It uses inter- disciplinary and trans-disciplinary ways of team o work, or sometimes it combines them to cause the easier ways for identification and success of musically talented children.

\section{BIBLIOGRAPHY}

1. Bogunović, B. (2008). Musical talent and successfullness. Beograd: Institut za pedagoška istraživanja.

2. Dalcroze J., E. (1965): Le rythme, la musique et l'éducation. Lausanne. Foetiseh

3. Gajić, O. (1999). Art - my chosen reality. Novi Sad: Savez pedagoških društava Vojvodine.

4. Gardner, H. (1983). Frames of mind: the theory of multiple inteligences. New York: Basic Books.

5. Gardner, H. (1997. Giftedness from a multiple intelligences perspective. in N. Colangelo \& G.A. (eds.), Handbook of gifted education. Boston: Allyn and Bacon.

6. Gordon, E. E. (1965/1995). Musical aptitude profile. Chicago: GIA.

7. Gordon, E. E. (1979). Primary measures of music audiation. Chicago: GIA.

8. Gordon, E., E. (1980, 1984). Learning Sequences in Music. Chicago: G.I.A. Publications, Inc., p. 11.

9. Gordon, E., E. (2001). Jump right in: The music curriculum, reference handbook for using learning sequence activities. Chicago: GIA

10. Glascoe, F., P. (1996). Cooperation with parents. Zagreb: Naklada Slap.

11. Huzjak, M. (2006). Abiliti, Talent and Creativity in the educational process. Odgojne znanosti, 8(1), 289-300.

12. Jaramillo María Cecilia Jonquera M., C. J. (noviembre, 2004). Métodos Históricos o Activos en Educación Musical. Revista Electrónica de LEEME (Lista Europea de Música en la Educación). No 14) http://musica.rediris.es.

13. Jeremić, B., Ognjenović, V., Brtka, V. (2011). Development factors of predi-sposition for plaing song. International Conference on information technology and development of education INTRO 2011 (p. 298 - 303). Zrenjanin: Tehnički fakultet "Mihajlo Pupin".

14. Jeremić, B. (2011). Jeremić B. (2011). Abiliti, Talent and Creativity - Hints. Obrazovna tehnologija, (3), 277 - 286.

15. Jeremić, B., \& Pavlović, M., (2011). The Nature, the Discovery and the Manifestation of Musical Talent at the Junior Primary School Age. In The Fifth International Scientific Conference „Methodology of working with talented students”. Subotica: Teachers' 
Faculty in Hungarian Teaching Language. pp . 436 - 448.

16. Jovanović, P. (1972). Help of family in developing children's interest in reading. Beograd: Srboštampa.

17. Jurić, V. (1988). Methods in the work of school pedagogists. Zagreb: Školska knjiga.

18. Koren, I. (1989). How to recognize and identify gifted students. Zagreb: Školske novine.

19. Landis, В. и Carder, Р. (1972). The Eclectic Curriculum in American Music Education: Contributions of Dalcrozel Kodaly, and Orff Washington, D.C.: Music Educators National Conference, 1972, p. 9.

20. Maksić, S. (2006). Fostering creativity in school. Beograd: Institut za pedagoška istraživanja.

21. Matijevič, M., \& Bognar, L. (2005). Didactics. Zagreb: Školska knjiga.

22. Mirković, R., K. (1998). The psychology of musical ability. Beograd: Zavod za udžbenike i nastavna sredstva.

23. Radičeva, D. (1997). Introduction to methods of teaching solfege. Novi Sad: Univerzitet u Novom Sadu.

24. Radovanović, V. (1989). Personality profile of gifted adolescents, creative efficiency and educational establishment of creative lines: the template for an educational model. Zbornik Instituta za pedagoška istraživanja (22), 124-132. Beograd: Institut za pedagoška istraživanja.

25. Suzić, N. (2001). The emotional dimension of motivation in teaching. Pedagogija, (3), 13-28.

26. Službeni glasnik RS, broj 76/10. (2010). Regulation on detailed instructions for determining the right to individual education plan, its implementation and evaluation. Beograd: Ministarstvo prosvete.

27. Taggart, C. C. (2011). Response to Edwin Gordon's "Early childhood music abuse: Misdeeds and Neglect". Visions of Research in Music Education, 17. Retrieved from http://www--usr.rider.edu/vrme /

28. Teplov, B., M.(1967). The psychology of musical ability. U Zbornik Muzičko - pedagoških radova. Sofija: Narodna prosveta.

29. Vučić, L. (1991). Educational psychology. Beograd: Društvo psihologa Srbije 